\title{
Sacred Ground: The Liberation of Alsace-Lorraine, 1944-1946 Serge Cipko
}

\begin{abstract}
Alsace-Lorraine, a region annexed from France by Germany in 1871 and recovered by France in 1918 , was reannexed by Germany once more following the fall of France in 1940. In 1944 French liberation forces embarked on an intense campaign to regain what it considered "sacred ground," and the French media projected an image of an Alsatian population enthusiastically endorsing this effort to be reunited with the rest of the country. A careful reading of documentary evidence, however, suggests that the process of liberation and the reintegration of the region into France did not proceed smoothly. The demands the liberation forces placed on the civilian population to join the military campaign against the Nazis, combined with the delicate issue of collaboration, the mutual distrust, the strenuous efforts to "reFrancocize" the region following four years of Nazification (a process which had included indoctrination, service in the Webrmacht, the installation of extermination camps in the territory, and collaboration), generated an ambiguous relationship between Charles de Gaulle's government and Alsatians. Official French policy in the region, which deviated from that practiced in the rest of France, reflected the circumstances peculiar to Alsace-Lorraine.
\end{abstract}

Certain historical and cultural peculiarities have distinguished Alsace-Lorraine, a region now comprising the three norcheastern French departments of Haut-Rhin and Bas Rhin (Alsace), and Moselle (Lorraine), from the rest of France. To begin with, the two provinces were incorporated into France only in the seventeenth and eighteenth centuries, after existing many years as independent states. Then in the nineteenth century, following the FrancoPrussian War of 1870-71, the new German Empire wrested them from France and declared them "Imperial Territories." Once more they became part of France on the defeat of Germany in World War I, only to be reannexed by the Nazis in 1940. The two provinces were returned to French rule following their liberation in 1945. 
Although politically these regions are constituent members of the French state, only a minority of their inhabitants have traditionally been French-speakers. The most common language has been German or a German dialect similar to thatspoken in parts of Switzerland. Cultural and historical attributes of Alsace-Lorraine have indeed been issues determining French and German claims to these territories, but they were not the only factors which determined the region's importance to the two countries. Geo-political and economic concerns have also played a part. The two frontier provinces lie across important communication roures for Central Europe. They are rich agriculturally, contain extensive mineral deposits, and are at the centre of an important textile industry.

During World War II, these endowments prompted Germany to annex Alsace-Lorraine, the only region of France to be incorporated into the Reich. German rule during the war radically altered society in Alsace-Lorraine. The inhabitants, their ties severed with the rest of France, underwent a process of Nazification. The Germans deported whole communities, established several concentration camps in the region, and drafted many of the youth into the German Army, the Wehrmacht.' Alsace-Lorraine, among the first regions to fall under German occupation, was also among the last to be liberated. Reunification of the region into the Republic would become the greatest challenge to Charles de Gaulle's cherished goal of French unity. To surrender Alsace-Lorraine to Germany would not only mean yielding "sacred ground," but also losing an essential and symbolic piece of French history. French national pride was at stake; the liberation of France was incomplete without the recovery of Alsace-Lorraine. French ambitions, however, were at odds with those of Germany, which equally considered Alsace-Lorraine a vital limb of its national body. Consequently, Alsace-Lorraine became a major bartle-ground between neighbouring contestants in the closing stages of World War II. The longest period of fighting in the French liberation campaign took place on its soil. With the assistance 
of its allies, the French liberation army emerged victorious and Alsace-Lorraine was restored to France in the spring of 1945.

The liberation struggle and the process of reintegration of Alsace-Lorraine did not proceed smoothly. French officials were unsure of the attitudes towards, and the degree of enthusiasm for, the struggle there during its crucial stage. Ambiguity can be deduced from the French press reports of the liberation campaign and its immediate aftermath, which extolled the heroic virtues of the people of Alsace-Lorraine to a point of incredulity. The reports stressed their sufferings and tribulations at the hands of the enemy and symbolically linked their current struggles to such moments in their history as the events of 1870-71 and 1918. The intentions behind these reports, consciously or unwittingly, appear to have been twofold: to gain the sympathy of the French public for the liberation effort in Alsace-Lorraine by drawing attention to its patriotic heritage and its Frenchness, and to reassure sceptics, both in Alsace-Lorraine and in the rest of France, that the region had not been abandoned but would soon be reunited with the rest of France (as so desired by its inhabitants).

But media reports that followed the liberation reveal the apocryphal nature of these accounts; for beneath the veneer of the depiction of a population enthusiastically responding to the call of overt resistance, the reports show that the people of Alsace-Lorraine were more concerned with self-preservation. Furthermore, tensions had mounted when the population, sustaining multiple privations because of the intense fighting in its territory, was required to aid combatants by rendering services and material assistance. (Later, these tensions would be heightened when the issue of collaboration was raised).

Not all issues pertaining to the liberation period of 1944-1946 have received adequate treatment in the historical studies of Alsace-Lorraine. In terms of general surveys, G. Foessel'sarticle on the liberation of Alsace restricts discussion of the liberation process to military operations in 1944- 
$1945^{2}$, while M. Parisse presents an equivalent evaluation of Lorraine during the same period in a very cursory manner. ${ }^{3}$ A more useful and detailed summary of the war and liberation periods can be found in F. G. Dreyfus's general history of the region. ${ }^{4}$ Dreyfus's study, albeit concise, presents a wider range of problematic issues intrinsic to the liberation period in Alsace-Lorraine than the aforementioned works.

Although nor dealing specifically with the liberation period, Philip Charles Farwell Bankwitz's Alsatian Autonomist Leaders $1919-1947^{5}$ is a study of particular value, since it provides insights into Alsatian attitudes prevalent before the German occupation, during the war years and in the war's immediate aftermath. Bankwitz's characterization of the Alsatian autonomist leaders in those years shows that the latter's loyalties were torn not so much between France and Germany, but more between home rule for the region and accommodation with the Nazi regime. The roots of the separatist movement in the region, in his view, stemmed from the reluctance of the Parisian government to pass decentralization legislation, although he notes that the movement also flourished in the years before the war as a result of German funding. ${ }^{6}$ The popularity that the autonomist cause enjoyed in Alsace-Lorraine in the prewar years is evident from the successes that one of the wings of the Union Populaire Republicaine party (UPR), a main advocate of autonomy, achieved in the legislative elections of May 1936. The UPR won most of the seats in the region in that election.' Indeed, by Seprember 1939 the French authorities were sufficiently concerned with the strength of the autonomist movement in Alsace-Lorraine and the links that the movement had with Germany to order the arrest of fifteen Alsatian autonomist leaders. ${ }^{8}$ Although the Germans subsequently released the leaders following the German invasion of France, their ambition of an autonomous AlsaceLorraine, according to Bankwitz, was not realized under the new Nazi regime. Nonetheless some of them did prosper financially during the occupation.' Regardless of what benefits were accrued, however, few Alsatians, even major 
collaborators, welcomed the German policy of extensively drafting unwilling local youth into the Wehrmacht, a practice which provoked widespread resentment and prompted riots in the region in February 1943. ${ }^{10}$ Yet, despite the German reports Bankwitz uses to argue that support for the occupying regime declined in Alsace-Lorraine, ${ }^{11}$ mass insurrection against the Nazi rulers never developed in Alsace-Lorraine.

Two other German documents to which Bankwitz also alludes in his study, demonstrate the peculiarity of the Alsatian situation in the latter stages of the war. One document, compiled by the Gestapo in the summer of 1944 , reported that 90 percent of the Alsatian population did not expect a German victory after the Normandy invasion of 6 June 1944. Another source, a Gestapo teletype sent on 20 November 1944, conveyed that "no riots on the part of the populace" were taking place in Alsace-Lorraine. ${ }^{12}$ Thus, although Alsatian society apparently harboured few illusions about a successful German conclusion to the war, and, as the evidence suggests, had generally grown more inimical to the Nazi regime as the war years progressed, no indigenous mass revolt emerged in the region. The ambiguous relationship between the Alsatian population and the French polity can explain the paradox of this lack of resistance. The German regime had deprived the Alsatians of any hopes of autonomy with its policy of Nazification, but the previous French administration had not regarded Alsatian autonomy much more favourably. French official evaluations of AlsaceLorraine's failure to resist the occupation forces and the region's prewar ties to Germany must also be considered: should Alsatians have expected reprisals to follow once their region had been recovered? Would the new French order have addressed Alsatian interests and concerns more significantly than previous administrations, or rather should Alsatians have expected that the identity and future of the region would once again be subordinated to the dictates of the centralized Parisian-based bureaucracy? Issues such as these are not the main focus of Bankwitz's study and thus, naturally, are not fully examined in his text. 
The French press, although at times presenting a distorted portrayal of circumstances in Alsace-Lorraine, offered a clearer perspective of how officials in France assessed developments in this border region. It has been possible therefore to determine some aspects of the equivocal bilateral relationship and to present other issues not covered thoroughly in the scholarly literature. The accounts of three major newspapers, Le Monde (the national newspaper), Combat (the newspaper of the French resistance), and L'Humanité (the organ of the Communist Party of France), provide a primary line of inquiry for this study. The focus of the present study is on the period from September 1944 to May 1946, with the former date marking the beginnings of the joint Allied campaign in Alsace-Lorraine and the latter date corresponding to the end of the war crimes trial of the ex-Gauleiter of Alsace, Robert Wagner. The issues to be examined to elucidate the bilateral relations of AlsaceLorraine are the liberation campaign, the concentration camps, Alsatians in the Wehrmacht and the process of reintegration.

As the joint Allied campaign for the liberation of Alsace-Lorraine commenced, the Germans offered determined resistance while the Allied forces gained ground slowly. To General Charles de Gaulle, then the president of the French Committee of National Liberation, the rapid liberation of Alsace-Lorraine wasessential not only to maintain national unity and personal credibility among supporters, but also to preserve an esprit de corpsamong his troops on the front. On 25 November 1945 De Gaulle was close to his objective after the Germans surrendered Strasbourg, ${ }^{13}$ now the capital of Bas Rhin, but the battle for Alsace was by no means over. German reinforcements were sent in to regain the ciry. An unusually severe winter complicated the Allied campaign, causing the front to stabilize momentarily. This deadlock dismayed the French participants in the campaign. One Army commander stressed to de Gaulle the deteriorating morale of the French troops on the front, attributing this "less to losses, fatigue and the hardships caused by the winter 
than to the spiritual isolation from the nation." 14 This revelation prompred de Gaulle to pay a visit to Alsace in late December with a view to raising the spirits of both the troops and the local inhabitants. ${ }^{\text {is }} \mathrm{He}$ described the impressions of his visit in the following terms: "The people were vehement in their demonstrations of patriotism, and their expressions of faith made it impossible to forget how severely the war had chastened every Alsatian hearth." ${ }^{16}$ The French media, particularly Combat, promoted a similar account of the situation in Alsace-Lorraine. ${ }^{17}$ It should be noted, however, that the Ministry of War censored the French press at this time. $^{18}$

As the battle for Alsace-Lorraine was raging, the French Red Cross appealed to citizens in France to assist and establish contacts with the people of this region. ${ }^{19}$ About this time government officials announced that the death penalty would be imposed on those in Alsace found aiding the enemy.$^{20}$ During de Gaulle's visit to Alsace, the enemy was beginning to make a breakthrough in the Ardennes, and the Allied Command had unilaterally decided to evacuate Alsace. To de Gaulle the decision was an insult. He declared to General Dwight Eisenhower, the Supreme Allied Commander, that "retreat in Alsace would yield French territory to the enemy .... For France, it would be a national disaster .... Alsace is sacred ground."21

A letter dated 2 January 1945 from General Lattre de Tassigny, Commander of the French First Army, to General Devers, Commander of the Sixth Army Group, echoed De Gaulle's response. Lattre de Tassigny urged that Strasbourg not be abandoned to the enemy, because

Strasbourg is a symbol of the resistance and the glory of France. The liberation of this town was the sign of French insurrection. Its abandonment would incite the French people to stop believing in victory and would also have repercussions throughout the world. It would bolster up German morale, although they are on the verge of defeat. ${ }^{22}$ 
The following day, the Mayor of Strasbourg, Charles Frey, also issued a protes ${ }^{23}$ and the indignation was similarly expressed within the Alsace-Lorraine Brigade of the Forces Franfaises de l'interieur (FFI). ${ }^{24}$ Amid these protests, the Supreme Allied Command relented and the evacuation measures were ordered cancelled. The intense battle for Alsace continued and by early February the liberation there was almost complete. As one participant in the liberation noted in his diary, "on 9 February 1945, at 8:00 in the morning ... the last German uniform has left the sacred ground, Alsace is liberated, the mission accomplished."25 Combat, however, did not declare the whole of Alsace liberated until 20 March $1945 .{ }^{26}$

In a letter to Eisenhower dated 29 September 1944, de Gaulle had stressed the importance of French military participation in the liberation of Strasbourg ${ }^{27}$ and undoubredly he considered that the greater the involvement of local forces the better. The activity of the FFI in Alsace can be traced to November $1943 .{ }^{28}$ It established contact with a local group called the Groupes Mobiles d'Alsace, which by May 1944 had 800 armed resistance fighters and which received the moral and material support of émigré Alsatians in Switzerland. ${ }^{29}$ In September 1944, as the FFl advanced into Alsace and Lorraine it established a brigade composed of local partisans called the Alsace-Lorraine Brigade (ALB). The ALB began to agitate among the local population in an effort to bolster its numbers. Typical of this endeavour was a placard posted in Remirement in October 1944, which read:

For the total liberation of France. For the liberation of Alsace-Lorraine. Do you want to serve in the Alsace-Lorraine Brigade? There you will find those who have been expelled, escapees, prisoners of the Gestapo, refugees, maquisards from all regions of France, all of them volunteers. ${ }^{30}$ 
It is difficult to determine what effect such appeals had on the population, but it is evident from the literature that assistance in the form of material goods was forthcoming as villagers furnished much needed provisions to the combatants. The tactics used by the propaganda staff of the FFI to rally Alsatians emphasized the patriotic character of the liberation, a liberation in which the natives of the region were playing a vital and historic role. Thus, the appeals issued by the FFI would be replete with references to the "Martyr French province of Alsace" or to a particular "Martyr French town of Alsace." Often, analogies would be drawn to glorious episodes of the region's past, especially to the previous liberation, as is well indicated in one declaration issued upon the capture of Strasbourg:

Twenty-six years and a day after the anniversary of 1918, France has regained Strasbourg .... People of Strasbourg: France and its allies will not repeat the mistake of yesterday, the invaders will not return. ${ }^{31}$

The tone of another declaration, however, implies that the FFI was impatient or frustrated with the lack of local voluntary initiative in assisting the liberation effort. "People of Starsbourg!" the manifesto declared, "The General Le Clerc, provisional military governor of Strasbourg, demands that the citizens of Strasbourg assist him today to continue the war." 32

As Alsace-Lorraine was being cleared of enemy troops, liberation forces encountered, in that the region, the most gruesome and notorious of Nazi institutions: concentration camps. The French press was more eager to report on those concentration camps situated elsewhere in Europe than the ones on French soil, but the latter, particularly those that had interned French citizens, did receive some publicity. Among the better known concentration camps were Struthof, Natzweiller and Schirmeck. Struthof, located some sixty miles southwest of Strasbourg, was by far the largest of the camps. Estimates of its size vary; L'Humanite reported in late 
October 1945 that the camp had contained 40,000 inmates, of whom 10,000 had perished, ${ }^{33}$ while the New York Times had a little earlier reported a total of 50,000-60,000 interned of whom at least 15,000 had been killed, most of them in the camp's crematorium. ${ }^{34}$ Combat simply noted that "thousands" of French patriots were killed in this camp under the orders of the executioner Kramer. ${ }^{35}$ When the camp was liberated in late 1944, the U.S. Seventh Army examined its captured records. It found that the composition of the inmates was diverse. According to one list of prisoners compiled just before the camp was liberated, the majority was described as "Aryans in protective custody." There were also a number of Jews, non-German civilian workers from occupied countries, prisoners of war from Eastern Europe, professional criminals, and various "dissenters" and other undesirable elements targeted for extermination. ${ }^{36}$

Curiously, shortly after their liberation, the camps of Struthof, Natzweiller, and Schirmeck assumed new functions as the French authorities began to use them to intern German prisoners of war. According to the New York Times, the French considered this new phenomenon "poetic justice." Germans who failed to escape were assembled into the camps. An ever-increasing number of locally arrested collaborators soon joined them. These inmates, however, received a far more humane treatment in these camps than did their predecessors under the old Nazi order. They were engaged in various public works, sweeping the roads and wood curting, and in kitchen work. They received adequate nourishment, although according to one report, hygiene in the barracks was unsatisfactory. ${ }^{37}$

The fact that the camps continued to operate alarmed the foreign press, and press reports, in turn, embarrassed officials in France who were anxious to dissociate the current usage of these camps from their Nazi past. One correspondent for Combat demanded that these camps be dissolved as quickly as possible and that their inmates be tried immediately by civil courts, so that those determined to be innocent could be set free sooner. ${ }^{38}$ 
While these camps have been the subject of some study, ${ }^{39}$ there is a suspicious lack of material relating to one camp, which held, nor French or West European inmates, but Sovier prisoners of war. The camp in question is the one at Ban-Saint-Jean, near Boulay in the department of Moselle. More than 200 mounds were found containing the corpses of well over 20,000 victims in what had been a former base camp for the Maginor Line. The New York Times reported in late October 1945 that "it appeared to be the largest such find yet made in France." 40 The victims had perished from starvation and other abuses; some had been buried alive. Surviving inmates of the camp erected a stele, on which were inscribed the words in Cyrillic: "To our 23,000 dead comrades." The Communist newspaper L'Humanité, expressed indignation at the crime. Such a gross number of victims, it said, was beyond the comprehension of the human mind. The perpetrators of these crimes, it concluded, should be pitilessly and severely punished. The newspaper also derived political significance from this mass murder. The graves, it argued, bore testimony to the sacrifices for liberation. But would this example, it wondered, be sufficient to silence the critics who minimized such (Communist) sacrifices? ${ }^{\text {t1 }}$

This reference to Ban-Saint-Jean was clearly more an exercise in rhetoric on the part of L'Humanité than an exhortation for action, for the newspaper never brought up the matter again. Admittedly, there would have been no reason to have raised the matter of the camp during Robert Wagner's war crimes trial in Alsace, as the camp in Lorraine was beyond his jurisdiction. But this raises the perplexing question as to why no similar war crimes trial took place in Lorraine (none had been publicized in the French press). Only one thing is certain in the mystery of the Ban-St-Jean affair: after the short items appeared in the French and international press between 31 October and 2 November $1945,{ }^{42}$ the press never brought up the camp again. The leading Soviet newspaper, Pravda, does not appear to have reported the event at all, while the special issue of the Revue 
d'histoire de la deuxième guerre mondiale ${ }^{43}$ devoted to Lorraine during the war and hence an obvious place for the camp to be discussed, does not allude to Ban-St-Jean even once.

A pressing issue for the French government in the immediate postliberation period was the repatriation of Alsatians who had been deported or were interned in prisoner of war camps across Europe. According to Henri Frenay, Commissioner of Prisoners and Deportees, 400,000 persons had been deported from Alsace-Lorraine during the war, "among this number we include the families of those deported and men enrolled by force in the Wehrmacht." 44 There was an inordinate number of Alsatians serving in the Wehrmacht and there are indications that, in August 1944, the Germans considered increasing the quota of Alsatians in the army to the limit by imposing a total mobilization in Alsace-Lorraine. is $^{\text {s }}$ In total 130,000 persons from Alsace-Lorraine were drafted into the Wehrmacht. Of this number 82,000 had been repatriated by the end of February 1946 and another 25,000 were known to have been killed. ${ }^{46}$ The French authorities insisted that these soldiers had served in the Wehrmacht against their will and they petitioned Allied governments to return those found incarcerated in their zones. In the autumn of 1945 the U.S. authorities assured the French government that they would act on this request and shortly afterwards the Soviet government gave a similar pledge. The French government was particularly concerned about the fate of those prisoners held by the Soviets. Revelations that 3,000 of the 10,000 Alsatians interned at the Soviet prison camp in Tambov, Russia, had died of exposure or of other forms of neglect heightened French concerns. ${ }^{47}$ The Soviets proved to be the most intransigent of the Allies on the repatriation issue. They maintained that the Germans had advised them that those Alsatians who had accompanied them on the Eastern Front had served in the Wehrmacht voluntarily. The French, for their part, insisted that those now in Soviet hands not be treated as German prisoners of war because the region they belong to had been forcibly annexed by Germany. ${ }^{48}$ For whatever reason, the Soviets 
were reluctant to oversee a rapid transfer of Alsatian prisoners to France.

The process of reintegrating Alsace-Lorraine, by all accounts, was a difficult one. The devastation of war had left the region in shambles. Roads in many areas had become impassable, material losses were extensive, and industrial activity had come to a virtual standstill. When a Combat correspondent visited Strasbourg in February 1945, he noted that the city had been heavily bombarded and that its population was reduced to half its prewar level. He also reported the problems of provisioning in the city and the fact that the population appeared to be ignoring the black market. In his experience, it was in vain to demand a waiter in one of the few still open restaurants to ferch him a packet of cigaretres, and "try to find a tavern in the city which would be able to serve you half a beer during the day." ${ }^{39}$ The industrial lull in the area had given rise to the problem of unemployment. The factories did not lack equipment and tools, but with major power-generating plants destroyed, safe industrial output was forestalled. The situation was best in the textile and footwear sectors, in which warehouses continued to carry stocks of clothing, but even in these industries stringent rationing precluded the widespread purchase of textiles and hence the factories suffered..$^{50}$

Price fixing and adjustment of workers' salaries contributed another quandary in the reintegration of the region into the French economic mainstream. Until March 1945, the German mark continued to be a currency of circulation in Alsace-Lorraine. ${ }^{51}$ The rate of exchange was set at 15 francs to one mark, leading observers to comment that the francin Alsace-Lorraine "had become a premium." 52 A related problem facing the new administrators in the region was that of maintaining an equilibrium in salaries. For instance, while unskilled workers in Alsace-Lorraine had been paid less than their counterparts in the rest of France during the Nazi occupation, certain strata of the labour force, such as civil servants, actually gained a significant increment in their salaries. ${ }^{53}$ Given these irregularities, the 
implementation of economic reforms was a more complex matter in Alsace-Lorraine than elsewhere in the country.

The ravages of war in the region left many inhabitants without their dwellings, and with few means to construct new homes. Such essentials for this purpose as cement, bricks, tiles, lime, plaster, and glass for windows, were scarce, as were such minerals as coal as a source of fuel. One could venture into nearby woods and forests in search of alternate materials and fuels, but only at great risk, for such places were teeming with undefused mines. ${ }^{54}$ The breakdown in communications (roads in disrepair, the telephone system rendered obsolete and motor vehicles requisitioned for the use of the army) led to the atomization of whole communities in the severe winter of 1944-45. Further irritants arose when Alsatians were required to service Allied soldiers operating in the region. This placed enormous pressure particularly on available accommodation. One reporter noted that "thousands" of dwellings and many of the hotels in the towns and cities had been requisitioned by army officers. 5 The requisition measures evoked ill-feeling among those affected by them, especially as it was perceived that some army officers were requisitioning more than was reasonable. Such abuses, according to one correspondent, "provoked among Alsatians an exasperation of nationalism, which has been converted into general hostility toward the Americans." 56

These requisition measures occurred almost simultaneously with waves of purges in the region, exacerbating tensions within the population and creating an awkward atmosphere of resentment toward the new regime. The process of arresting collaborators began as soon as the FFI entered a liberated zone, ${ }^{57}$ but often the arrests would be conducted in a disorderly and arbitrary manner. ${ }^{58}$ An example of the lack of confidence the FFI had in the Alsatian populace is provided in the case of the small town of Dornach where 41 men, women, and children were arrested indiscriminately and erroneously, on suspicion of having sabotaged a local relephone cable. ${ }^{59}$ 
The purging committees which accompanied the liberation had originally sprung up spontaneously, only assuming an institutional character in the summer of 1945 , when legal Investigating Commissions were created. The Commissions were set up in each district of Alsace-Lorraine, and were presided over by three appointed citizens and assisted by a police inspector and a screening committee. Investigating Commissioners ordered all Alsatian citizens in their districts to fill out a questionnaire detailing their military, civilian, and political wartime activities. This procedure disgruntled many Alsatians who believed that such a formality stereotyped them as a society of Nazi collaborators ${ }^{60}$ Furthermore, although the purging process had now assumed a formal character, irregularities in the implementation of arrests occurred. An article featured by Combat in October 1945 noted that while some citizens in Alsace-Lorraine had been penalized for collaborating in the occupation administration, coordinating labour mobilization, or for having conducted agitation in favour of the Nazis, others, guilty of the same crimes, remained free. Some, who were now interned in prison camps across the provinces, had been arrested solely on the basis of a denunciation by a neighbour probably anxious to settle old scores. Others close to the accused had presented affidavits attesting that they had been "good French citizens" who had been forced into Nazi organizations. The writer of the article in Combat concluded that the purging process in Alsace-Lorraine was more complicated there than elsewhere in France, because it was difficult to distinguish between those who had joined Nazi organizations voluntarily and those who had been forced to do so. ${ }^{61}$ Given the significant number of Alsatians who had joined Nazi organizations during the occupation, under coercion or otherwise, the removal of voting privileges from all such "collaborators" would affect a considerable number in the region and would thus create still greater resentment. ${ }^{62}$

It has been estimated that the total number of persons arrested on charges of collaboration in Alsace-Lorraine falls 
between 8,000 and $10,000 .{ }^{63}$ In the department of Bas Rhin some 1,215 functionaries had been sanctioned following the liberation. Nearly a quarter of the staff at primary schools and one third of those at secondary schools were purged in Alsace. ${ }^{64}$ In January 1945, when much of Alsace was back in French hands, a major reorganization of municipal leadership took place. Some nineteen mayors were appointed for the first time under the new regime, another thirty mayors who had been forced underground during the Nazi occupation were reinstated, while a further twelve who had continued serving during the war in the region, were retained. ${ }^{\text {os }}$

While the purges and arrests were significant by French standards, at least in absolute terms, the actual number of executions for war crimes and collaboration in Alsace-Lorraine fell far below the national average ${ }^{66}$ In his study of the purging of collaborators in liberated France Peter Novick found that:

The special circumstances of incorporation [of Alsace-Lorraine] into the Reich produced a unique situation, statistically and otherwise: even with the highest percentage of quashed indictments of any district, there were more cases brought to trial, and more guilty verdicts as a percentage of the population, than anywhere else. At the same time, because of the same special circumstances, death sentences were rarer in Alsace-Lorraine than anywhere else. ${ }^{67}$

The disproportionately low rate of executions and the largescale release of prisoners shortly after their arrest could also be interpreted as a sign that the new regime probably expected to defuse tensions in the region by minimizing the number of convictions. Having just repossessed the region, the new regime could ill-afford to alienate the population (whose sympathies for the new order appear to have been ambiguous) by staging trials which, while certainly legitimate in the cases of those whose actions during the war were 
questionable, might arouse the hostility of Alsatians, and thus present a potential breech of national security.

The economic and administrative reforms following the liberation were accompanied by efforts to link the region as fully as possible to the cultural institutions of the rest of the nation. Such an ambitious programme of assimilation, however, required a degree of legitimacy and support before it could be realized. The national press of the period reveals two trends that appear to be closely connected with this phase of reintegration. The first was the tendency of Alsatians to send patriotic letters to Le Monde, letrers that stressed the Frenchness of the region. The press also reported remarkably frequent visits of government ministers and by de Gaulle himself to Alsace-Lorraine in the months after the liberation.

The letters to Le Monde, which constituted the bulk of all letters published in national newspapers between February and September 1945, have one common trait: they are aimed at assuring the French nation that the Alsatians are ready to resume citizenship after years of artificial separation. An article in Le Monde in mid-February 1945 by M. Louis Marin, a celebrated deputy of Nancy, stressed the continuous suffering and heroism in Lorraine's history. ${ }^{68} \mathrm{~A}$ week later, a native of Alsace-Lorraine, Gaston L'Huillier, declared that it was high time Alsace-Lorraine be referred to not by its popular historical designation, but by its individual constituent departments. ${ }^{69}$ Some days later, an article by Jacques Leron traced the history of Lorraine from the thirteenth century, describing, among other things, the origins of the Cross of Lorraine, the very insignia adopted by de Gaulle for the Free French Army. The other letters and articles by Alsatians berween March and September were similarly patriotic in tone. ${ }^{70}$

Between the summer of 1945 and the spring of 1946 several prominent members of the government from Paris visited Alsace-Lorraine to discuss policy matters with local depuries. The visits also served as occasions to make public appearances among the people. For instance, in July 1945 the Minister of Prisoners, Deportees, and Refugees, on his 
visit to Alsace, attended the inauguration of a new metal bridge in Strasbourg. In his inauguration speech he emphasized the contrast between the two sides of the Rhine. On one side of the bridge, he remarked, is France, and "here begins the country of liberation, as is beautifully illustrated by the tri-coloured placard on the bank to the right."71 In October 1945 de Gaulle visited Strasbourg. In a public address he exalted the city's qualities and its proud tradition in French history. ${ }^{72}$ Two months later, he returned to Alsace-Lorraine with several ministers, paying calls to the major urban centres in the three departments. In his speeches he praised the Alsatians' "fidelity to the French nation" and urged them to participate in the building of the new, liberated France. During his visits he announced the donation of a sum of one million francs to the city of Strasbourg and to the prefect of Moselle for relief purposes. ${ }^{73}$ A speech delivered by Felix Gouin, the President of the Constituent Assembly, was cast in a similar patriotic vein. ${ }^{74}$

Communists too, tended to stress the Frenchness of the region and called for its speedy reintegration into the country's cultural mainstream. At the turn of 1946, a Communist depury, Marcel Rosenblatt, in a discussion of the budget proposed by the Constituent National Assembly, demanded more rextbooks in Alsace-Lorraine to facilitate instruction in French. He also called for the secularization of education in the three departments. The desire of the Communist group, he explained, was to "make Alsace a bastion of French culture, secular and republican." 75 The shortage of French rextbooks in Alsace-Lorraine had already been publicized in Le Monde in late July 1945. The newspaper noted that the youth of the three departments, "after years of annexation and oppression deeply aspire to be reunited with our culture," but lamented that to date there had been a severe lack of French texts for the youth. In an effort to fill the void, the report in Le Monde continued, the semi-official body, Entr'aide Francaise, was making available 700,000 volumes for distribution in educational establishments in 
the region, ${ }^{76}$ a remarkable amount considering the acute paper shortages prevailing in France at this time.

Following the efforts of groups such as Entraide Francaise, the French government began to enact laws to promote French culture in Alsace-Lorraine. In January 1946, for instance, the Ministry of Information announced that bilingual journals in Alsace were required to contain 25 per cent of their texts in French in the departments of HautRhin and Bas Rhin. It added that all periodicals were to heed this requirement except the L'Alsace illustree of Mulhouse and the Jeunesse ouvriere d'Alsace of Strasbourg, which were instructed to feature 50 per cent and 75 per cent, respectively, of their contents in French. It also stipulated that in the department of Moselle, Lorraine, bilingual journals should allocate no less than 40 per cent of their contents to French. ${ }^{77}$ The differences in proportions perhaps reflect the policymakers' perceptions of the most effective media to transmit French culture and of which districts required greater efforts at assimilation.

On 23 April 1946 France's "Nuremberg" opened in Strasbourg when Robert Wagner, the ex-Gauleiter of Alsace, and a number of his associates were brought before a military tribunal on charges of war crimes. Wagner, along with three accomplices, Roehn, Schupel, and Goedecke, were accused of "provoking the French to bear arms against France"; disseminating propaganda for the Wehrmacht and Waffen SS; exploiting French resources for the benefit of the Reich, but to the detriment of France; violating individual liberties; implementing racial laws; and persecuting and expelling Jews and Alsatians loyal to France. On another count, Wagner was accused of ordering one of his subordinates, Hugo Gruner, the Nazi district leader of Thann, Alsace, to execute four British aviators and a number of Alsatian patriots. He was also held responsible for the atrocities committed in the extermination camps of Struthof and Schirmeck. ${ }^{78}$ The German defence lawyers for Wagner contended that he should not be tried by a French court because the crimes he was accused of were committed in 
German soil and what exploitation took place in Alsace was directed against Britain, not France. ${ }^{79}$

The Wagner trial, although little emphasized in the media reports, brought to the fore again the delicate issue of collaboration. Wagner insinuated during the trial, for instance, that the German annexation of Alsace had been approved by a tacit accord between Berlin and Vichy. ${ }^{80}$ When questioned about young Alsatians serving in the Wehrmacht. Wagner insisted that Alsatian soldiers had enlisted voluntarily. ${ }^{81}$ It was acknowledged later, however, that resistance to the drafting of Alsatians into the German Army could have been punishable by death. ${ }^{82}$ The implications of this is clear from the preceding discussion of the fate of the tens of thousands of Alsatians who were conscripted, many of them by force.

A more sensitive issue brought forth in the trial concerned the Alsatian autonomist movement. Wagner testified that he himself and his aides had maintained contacts with Alsatian separatists both before and during the war. ${ }^{83}$ These revelations prompred Combat to present a clarification of Alsatian wartime activities. Its reports reassured readers that autonomist groupings in Alsace were more the exception than the rule, and maintained that of the one million inhabitants of the region only 27,000, "for the most part forced," were members of the Nazi party. It concluded that most Alsatians opposed the policies of Wagner and his Nazi assistants. ${ }^{84}$ On 3 May 1946 the court found Wagner, along with Roehn, his assistant Goedecke, his Chief of Cabinet, and Schuppel, his Chief of Staff, guilty of war crimes and sentenced them to death and ordered that their property be confiscated. Gruner, the ex-Kraisleiter of Thann, was also condemned to deach. This verdict, stated a correspondent for Combat, was one that the Alsace had been waiting for since $1940 .{ }^{85}$

The Wagner trial closed a confusing chapter in the history of Alsace-Lorraine, a region which has now been fully reintegrated into the political fabric of the French nation. That French political leaders feared the prospect of 
losing sovereignty indefinitely over their northeastern border provinces is clear from the strenuous military efforts made to regain them from the Germans in 1944-45, the propaganda campaign of the media stressing the "Frenchness" and consistent heroic virtues of the Alsatians in the nation's history, and the frequent visits of state ministers to the region in the liberation period and shortly thereafter.

The process of reintegration was not a smooth one; a degree of mutual distrust appears to have characterized relations between "liberators" and "natives" in the immediate postliberation period. In order for Alsace-Lorraine to be "French" again, however, the new government had to convince its inhabitants of the advantages of resuming citizenship in the Republic. Inordinate flattery could not suffice to gain the loyalty of a people whose recent history was marked by segregation from a nation with which it had less than two decades of experience. Indeed, the AlsaceLorraine of the pre-1870 era was an even more distant memory.

The new French order did not repeat the extensive abuses and repression associated with the Nazi occupation, and its retribution for collaboration was relatively moderate when compared with that experienced in the rest of the nation. Furthermore, the postliberation polity offered the region a stake in the future of the "New France" as a partner. Some cangible benefits have since resulted for the region in the form of its rapid industrialization after the war and in raising the prestige of its foremost city, Strasbourg. AlsaceLorraine may or may not be, as Marcel Rosenblatt had once hoped, "the bastion of French culture," and France may well begin there, as a former minister had implied in an inauguration address in July 1945. But what is certain is that the city of Strasbourg has recently assumed a new, cosmopolitan identity. Now, some two centuries later, Strasbourg is the seat of the Council of Europe, where, among the participants who meet on a regularly to discuss policies of mutual relevance, are delegates of two countries, France and Germany, which had traditionally vied for its 
180 Past Imperfect

possession. Strasbourg, once a "free city" during the Holy Roman Empire, is now, some might say, a European city. 


\section{NOTES}

' For a discussion of Alsace-Lorraine under Nazi occupation, see the collection of articles, "La Lorraine pendant la guerre," in Revued'histoire de la deuxieme guerre mondiale 105. (January 1977); also, Norman Rich, Hitler's War Aims: The Establishment of the New Order (New York, 1974), 231-239, and Charles Béne, L'A Lsace dans les griffes nazies(Raonl'Etape, 1973).

${ }^{2}$ G. Foessel, "Libérer le pays (octobre 1944-mars 1945)," in L'Alsace de 1900 d nos jours (Toulouse, 1979), 219-231

${ }^{3}$ Michel Parisse, Histoire de la Lorraine (Toulouse, 1977), 419-443

${ }^{4}$ François-Georges Dreyfus, Histoire de L'Alsace(Hachette, 1979), 331363

'Philip Charles Farwell Bankwitz, Alsatian Autonomist Leaders 1919. 1945 (Lawrence, Kansas, 1978)

6 Ibid., 19

'Ibid., 33

${ }^{8}$ Ibid., 34

9 Ibid., 83-84; 94

${ }^{10}$ Ibid., 76

"See Ibid., 74

12 lbid., 98

${ }^{13}$ Charles de Gaulle, War Memoirs: Salvation 1944-1946 Vol.3, pt.1 (London, 1959), 137

14 Ibid., 140

is Ibid., 141

${ }^{16}$ Ibid., 142

${ }^{17}$ See, for instance, Combat, 25 September 1944, 26 September 1944, 23 November 1944, and 28 November 1944 . See also L'Humanite, 261 27 November 1944.

${ }^{18}$ For instance. Paul Bodin, a regular reporter for Combat on events in Alsace, had one article completely censored on 13 January, 1945.

${ }^{19}$ Combat, 8 December 1944

${ }^{20}$ Combat, 5 December 1944. The impression given in this report is that the threat of the death penalty only applied to ethnic German settlers in the region.

${ }^{21}$ De Gaulle, War Memoirs, 147

${ }^{22}$ Charles de Gaulle, War Memoirs: Salvation 1944-1946 (Documents) (London, 1960), 205-206

${ }^{23}$ Ibid., 210

${ }^{24}$ Léon Mercadet, La Brigade Alsace-Lorraine (Paris, 1984), 248

${ }^{25}$ Ibid., 265

${ }^{26}$ Combat, 20 March 1945

${ }^{27}$ De Gaulle, War Memoirs (Documents), 196

${ }^{28}$ Fernand L'Huillier, Libération de L'Alsace (Paris, 1975), 46

29 Ibid., 48 


\section{Past Imperfect}

${ }^{30}$ Ibid., 195; see also Mercadet. La Brigade Alsace-Lorraine, 195.

"L'Huillier, Liberation de L'Alsace, 190

32 Ibid., 93. According to L'Huillier, 151, at its peak, the AlsaceLorraine Brigade did not exceed 2,200 in strength. It drew its members more from the urban districts than from the countryside, as can be gleaned from the social composition of the brigade's combatants: 40 per cent were white-collar workers (petits employes), 35 per cent labourers, 5 per cent railway employees, and 20 per cent farmers.

"L'Humanite, 23 October 1945

* New York Times, 1 October 1945

"Combat, 5 October 1945

${ }^{36}$ New York Times. 1 October 1945; For a harrowing description of Natzweiller, see New York Times, 8 January 1945.

${ }^{37}$ New York Times. 1 October 1945; for a different perspective, see Combat, 7/8 October 1945; see also L'Huillier, Liberation de L'Alsace. 177.

1" Combat, 5 October 1945

39 See the items listed for France in Andrea Devoto, L'Oppressione Nazista: Considerazioni e bibliografia 1963-1981 (n.p.: Leo S. Olshki Editore, 1983).

to New York Times, 31 October 1945

11 L'Humanite, 1 November 1945

12 Le Monde, 1 November 1945; New York Times, 31 October 1945 and 2 November 1945; Combat, 31 October 1945; L'Humanite, 31 October 1945 and 1 November 1945. The majority of the inmates appear to have been Ukrainian. See Encyclopedia of Ukraine Vol. 1, A-F (Toronto, 1984), 936.

${ }^{43}$ See note 1.

4 Combat. 7 September 1944

4" Combat, 28 August 1944

46 Combat, 21 February 1946

${ }^{47}$ Le Monde, 27 December 1945

48 Le Monde, 23/24 September 1945 and 27 September 1945

${ }^{49}$ Combat, 12 February 1945. The problems with provisioning persisted through to 1946. The winter of $1945-46$ proved to be as severe as the one preceding it, with similar detrimental consequences. In December 1945. 130 train wagons arrived at the Strasbourg-Neudorf railway station carrying frozen potatoes and so 70,000 Alsatians had to make do without their potato rations that month. See Le Monde, 12 December 1945.

sn Ibid.

"De Gaulle, War Memoirs (Documents), 171

'Combat, 12 February 1945

33 Ibid.

st Combat. 7 August 1945 
"Ibid.

is Combat, 8 August 1945

"' L'Huillier, Liberation de L'Alsace, 145

s8 Combat, 8 August 1945

"L'Huillier, Liberation de L'Alsace, 151

${ }^{60}$ Combat, 8 August 1945

61 Combat, 6 October 1945

${ }^{62}$ Combat, 8 August 1945

63 L'Huillier, Liberation de L'Alsace, 180. One source in 1948 quoted by L'Huillier estimated 45,000 arrests.

4 Ibid., 193

6s Le Monde, 6 January 1945

66 See, for instance, Robert Dodin, "Les F.F.I. en Lorraine," Revue d'histoire de la deuxiéme guerre mondiale no. 105 (January 1977): 78. 6: Peter Novick. The Resistance Versus Vichy: The Purge of Collaborators in Liberated France (New York, 1968), 164n. Bankwitz advances the same conclusion: "Compared with France as a whole," he writes, "more guilty verdicts as a percentage of the Alsatian population were rendered, but because of the exceptional conditions of the region's incorporation into the Reich, fewer death sentences were passed than in the country as a whole." Banwitz, Alsatian Autonomist Leaders 1919-1947, 107 108.

6s Le Monde, 15 February 1945

${ }^{69}$ Le Monde, 23 February 1945

${ }^{70}$ See, for instance, Le Monde, 23 March 1945 and 6 September 1945. Considering that Le Monde had government and Gaullist connections it is conceivable that these letters and articles were officially-inspired.

7 Le Monde, 10 July 1945

72 Le Monde, $7 / 8$ October 1945

"Le Monde, 13 December 1945

74 Le Monde, 26 March 1946

7 Le Monde, 12 December 1945

${ }^{76}$ Le Monde, 31 July 1945

7 Le Monde, 13/14 January 1946

${ }^{78}$ Combat, 24 April 1946. The trial was also reported in L'Humanite, Le Monde, and in abridged form, in the New York Times and in the London Times.

79 Combat, 24 April 1946

${ }^{80}$ Combat, 25 April 1946. There were no provisions in the armistice agreement with France of 1940 transferring jurisdiction of AlsaceLorraine to Germany. Alsace and Lorraine were politically separated from each other following the annexation. Wagner headed the administration in Alsace, while Josef Bürckel became Gauleiter of Lorraine, which was merged with the Saar and Palatinate to form the "Westmark." 


\section{Past Imperfect}

81 Combat, 27 April 1946

${ }^{92}$ Combat, 28/29 April 1946

Bs Combat, 30 April 1946

s4 Combat, 2 May 1946

8s Combat, 4 May 1946. They were executed on 14 August 1946. 